\title{
Effectiveness of Behavioral Counseling Model of Modeling Techniques for Developing Self Exhibition
}

\author{
Efektivitas Model Konseling Behavioral Teknik Modeling untuk mengembangkan Self Exhibition
}

\author{
Gusti Agung Aditya Nata Putra ${ }^{1}$, I Ketut Dharsana ${ }^{2}$, Ari Darmayanti ${ }^{3}$ \\ ${ }^{123}$ Universitas Pendidikan Ganesha \\ e-mail: agungaditya@gmai.com
}

Received August 03, 2017 Revised September 19, 2017 Accepted November 20, 2017 Published Online December 30, 2017

\section{Conflict of Interest} Disclosures:

The authors declare that they have no significant competing financial, professional or personal interests that might have influenced the performance or presentation of the work described in this manuscript.

\begin{abstract}
This research conducted at SMA LAB Undiksha Singaraja. The type that is "experimental" research with the research design is Group yaitu Control Group Pretes-Postest Group. This study aims to determine the effectiveness of modeling model of behavioral counseling model through lesson study in developing "self exhibition" of students in the eleventh grade of social class at SMA Lab Undiksha Singaraja. The dependent variable in this research is Self Exhibition, while the independent variable is behavioral cognitive counseling with self management strategy by considering the moderator variable in the form of the birth order of the students. This study uses data collection methods such as observation, questionnaires, interviews and diaries. The results of this study are students of the eleventh grade of social class at SMA Lab Undiksha Singaraja, showing symptoms of low self-exhibition and behavioral counseling model using modeling techniques have proven effective in developing self-exhibition students.
\end{abstract}

Keywords: behavioral counseling, self exhibition, lesson study.

\begin{abstract}
Abstrak: Penelitian ini dilakukan di SMA LAB Undiksha Singaraja. Jenis penelitian yang digunakan dalam adalah penelitian "eksperimen" dengan rancangan penelitian yaitu Control Group Pretes-Postest Group. Penelitian ini bertujuan untuk mengetahui efektivitas teknik modeling model konseling behavioral melalui lesson study dalam mengembangkan "self exhibition" siswa kelas XI IS SMA Lab Undiksha Singaraja. Variabel terikat dalam penelitian ini adalah Self Exhibition, sedangkan variabel bebasnya adalah konseling kognitif behavioral dengan strategi managemen diri dengan mempertimbangkan variabel moderator berupa urutan kelahiran siswa. Penelitian ini menggunakan metode pengumpulan data berupa observasi, kuesioner,wawancara dan buku harian. Hasil penelitian ini adalah siswa kelas XI IS SMA Laboratorium Undiksha, menunjukkan gejala-gejala self exhibition yang rendah dan model konseling behavioral teknik modeling telah terbukti efektif dalam mengembangkan self exhibition siswa.
\end{abstract}

Kata Kunci: konseling behavioral, self exhibition, lesson study

How to Cite: Putra, G. A. A. N., Dharsana, I. K., \& Darmayanti, A. (2017). Effectiveness of Behavioral Counseling Model of M odeling Techniques for Developing Self Exhibition. Bisma, 1(2), 69-76. https://doi.org/10.23887/128172017 


\section{Pendahuluan}

Pengamatan peneliti di kelas XI IS SMA LAB UNDIKSHA Pelajaran 2016-2017, peneliti melihat ada beberapa siswa yang memiliki gejala dan prilaku tidak mengerjakan pekerjaan sampai selesai, tidak mau berusaha mengerjakan pekerjaan sampai tuntas, dan mengeluarkan celetukan sesekali namun menimbulkan gelak tawa di dalam kelas. Namun tidak semua siswa memiliki kepribadian yang sama, ada juga siswa yang mampu menunjukkan sikaf menghibur teman dengan lelucon, mengembangkan kemampuan menceritakan hal yang humoris kepada teman-temannya, sulit mengembangkan mengarang sebuah cerita yang humoris kedalam sebuah tulisan.

Hasil wawancara dan observasi yang dilakukan terhadap siswa di kelas XI SMA LAB UNDIKSHA SINGARAJA, diketahui bahwa terdapat sebagian siswa yang mengalami gejala-gejala "self exhibition" kebutuhan untuk menonjolkan diri meliputi mengatakan sesuatu yang lucu, logis dan nalar, menceritakan cerita-cerita dan lelucon yang lucu, berbicara tentang pengalaman dan pribadinya sendiri".

Menurut Dharsana (2013:2) "Exhibition ialah kebutuhan untuk menonjolkan diri meliputi mengatakan sesuatu yang lucu, logis dan nalar, menceritakan cerita-cerita dan lelucon yang lucu, berbicara tentang pengalaman dan pribadinya sendiri". Sedangkan menurut Murray (dalam Alwisol, 2005:220) "Exhibition adalah kebutuhan untuk selalu mengesankan, dilihat, dan didengar, membuat orang lain kagum, bergairah, terpesona, terhibur, terkejut, terangsang, terpikat, menjadi pusat perhatian, menonjolkan prestasi, dan menyatakan keberhasilannya". Sejalan dengan pendapat di atas, Sukardi mengatakan (1993 : 5), "Exhibition (Exh) atau eksibisi, yaitu kebutuhan atau dorongan untuk memperlihatkan diri agar menjadi pusat perhatian orang, menceritakan keberhasilan diri, menggunakan kata-kata yang tidak dipahami orang lain, bertanya yang tidak akan terjawab orang lain, menceritakan pengalaman diri yang membahayakan, menceritakan hal-hal yang menggelikan". Berdasarkan pemaparan definisi tersebut, maka dalam penelitian ini yang dimaksud dengan self-exhibition adalah kepribadian yang dimiliki oleh seseorang untuk selalu menonjolkan potensi diri supaya menjadi pusat perhatian orang lain yang dilakukan dengan cara mengatakan sesuatu yang lucu, memikirkan hal yang logis dan nalar, menceritakan lelucon yang lucu, menceritakan pengalaman pribadi dan keberhasilan dirinya sebagai bentuk aktualisasi diri.(Aguiton et al., 2009; Cogo \& Dewey, 2006; Cova \& Pace, 2006; Friedman \& Miller-Herringer, 1991; Lotte \& Renard, 2008; ML Hamilton, 2002; Nielsen \& Dissanayake, 2004; Salmi, Vainikainen, \& Thuneberg, 2015; Zhao, Salehi, \& Naranjit, 2013)

Mengingat semakin minimnya sikap menonjolkan diri dengan menunjukkan kelucuan siswa, bersikap humoris unutk membantu meningkatkan ketenangan dalam belajar maka diperlukan upaya untuk membantu siswa menumbuhkan sikap kepribadian dalam dirinya, atau yang disebut dengan self exhibition yang dalam kegiatan interaksi sosial dapat dilakukan dengan pemberian layanan konseling. Pemberian layanan bimbingan konseling sangatlah penting bagi siswa.

Self Exhibition sangat berpengaruh dalam usaha mengembangkan kepribadian siswa, sehingga sekolah menggunakan berbagai usaha dalam mengembangkan kepribadin exhibition siswa, diantara lain yaitu pendidikan, pelatihan dan melalui layanan Bimbingan dan Konseling, sehingga oleh guru BK dilakukan berbagai aplikasi layanan yang mampu kiranya mengembangkan self exhibition siswa.

Berdasarkan pemaparan gejala tingkah laku yang diperoleh melalui observasi maupun wawancara, maka adapun usaha yang dapat dilakukan untuk mengatasi masalah yang berkaitan dengan self exhibition yang rendah dapat dilakukan berbagai pendekatan, antara lain: (1) pendidikan, (2) pelatihan, (3) bimbingan, (4) konseling. Dalam penelitian ini lebih menekankan pada tingkah laku (behavior) dan pola pikir (kognitif), maka peneliti melakukan pendekatan melalui bimbingan konseling. Salah satu cara yang dapat digunakan untuk mengubah perilaku negatif menjadi perilaku yang lebih positif dan sekaligus mengubah pola fikir siswa terhadap perilaku yaitu dengan Teori Konseling Kognitif Behavioral (CBT). Konseling kognitif behavioral adalah suatu proses untuk mengembangkan self exhibition dengan langkahlangkah sebagai berikut: 1) mengidentifikasi perilaku, 2)menganalisis perilaku, 3) menyimpulkan perilaku, 4) menyimpulkan indikator-indikator perilaku, 5) mendiagnosa perilaku, 6) melakukan prognosa perilaku, 7) mentreatmen perilaku, 8) mengevaluasi perilaku, 9) merefleksi perilaku, 10) memfollow-up perilaku. Menurut Dharsana (2014:258), "kognitif behavioral adalah suatu teori secara menyeluruh dan juga suatu usaha berdasarkan percobaan untuk menjelaskan prinsip dan kaidah-kaidah bagaimana tingkah laku manusia dipelajari melalui respon-respon sebelum tingkah laku muncul yang diyakini oleh konseli dan sebagai sebab dari munculnya perilaku baru. 
Bimbingan konseling merupakan proses mengoptimalkan potensi peserta didik, adapun tujuan dan fungsi dari bimbingan konseling adalah untuk membantu individu dalam mengembangkan potensi diri secara optimal sesuai dengan tahap perkembangan dan predisposisi yang dimiliki, seperti kemampuan dasar, bakat dan minat individu sehingga dalam perkembangannya akan mampu sesuai dengan arah kemampuan dirinya, selain itu adapun yang merupakan tujuan khusus dari bimbingan konseling adalah untuk membantu individu dalam mengentaskan permasalahan yang sedang dihadapi baik dalam belajar, kehidupan sosial, pribadi maupun arah studi lanjut atau karir siswa, sehingga keseluruhan tentang siswa menjadi ranah dari kegiatan bimbingan konseling, baik belajar, karir, pribadi maupun hal yang mencangkup studi lanjut dan persiapan karir siswa. Fungsi dari bimbingan konseling ada empat, yaitu: (1) fungsi pemahaman, (2)pencegahan, (3) Pengentasan dan (4) Advokasi.

Berdasarkan pemaparan di atas, kaitannya dengan penelitian ini adalah bimbingan konseling memiliki peran sebagai pedoman dan acuan bagi penelitia dalam melaksanakan penelitian, baik prosedur maupun langkah-langkah yang akan digunakan oleh peneliti akan disesuaikan dengan prosedur dan langkahlangkah dari konseling pada umumnya dan juga berpatokan dengan prosedur dan langkan konseling kognitif behavioral. Bimbingan konseling berorientasi pada siswa, perhatian BK adalah perkembangan siswa. Membelajarkan siswa merupakan sebuah proses yang bertujuan untuk membangun siswa, proses membangun untuk menjadikan siswa lebih mandiri dan juga tentunya menjadi pribadi yang bertanggung jawab terhadap dirinya sendiri.

Terlebih lagi adanya hasil pengamatan dilapangan yang menunjukkan beberapa gejala dari perilaku siswa, berdasarkan hasil pengamatan bahwa sebagian siswa menunjukkan perilaku melamun di dalam kelas saat guru sedang menjelaskan materi pelajaran, siswa mengobrol, tidak mencatat materi pelajaran yang sedang dijelaskan, sebagian siswa juga menunjukkan ketidak-aktifan dikelas ketika ditunjuk untuk menjawab pertanyaan guru, kemudian beberapa orang siswa terlihat dengan santainya beberapa kali keluar masuk kelas ketika guru sedang menjelaskan materi pelajaran. Namun sebagian siswa juga menunjukkan perilaku sebaliknya, yaitu sangat memperhatikan guru ketika sedang menjelaskan pelajaran dengan mencatat dan memperhatikan beliau dan terfokus pada kegiatan belajar. Sehingga bagi peneliti, berdasarkan hasil observasi tersebut diatas bahwa terdapat dua jenis perilaku yang jelas ditunjukkan oleh siswa, yaitu perilaku mengabaikan pentingnya pendidikan dan perilaku memperhatikan pentingnya pendidikan.Tanggung jawab belajar yang rendah kemudian dikaitkan oleh peneliti dengan self-exhibition siswa yang rendah.

Terkait self exhibition siswa di kelas tidaklah cukup jika dilihat hanya dari respon siswa saat pemberian pelajaran dikelas oleh guru mata pelajaran tertentu saja, karena ketidak-berhasilan yang ditunjukkan tidak pasti disebabkan oleh mereka kurang mengerti dengan pelajaran yang diberikan, tidak pasti juga penyampaian oleh guru terkait kurang menarik, oleh karena itu dilakukan pengamatan langsung ke dalam kelas terkait untuk mengamati beberapa pola tingkah laku yang ditunjukkan oleh siswa dan mengidentifikasi penyebabnya.

Pengamatan dilakukan dengan beberapa metode, yaitu observasi untuk mengetahui beberapa pola tingkah laku yang ditunjukkan langsung oleh siswa di dalam kelas selama mengikuti kegiatan belajar mengajar terkait dengan self exhibition siswa dan juga dilakukan proses wawancara dengan guru-guru mata pelajaran yang mengampu kelas XI untuk memperoleh perbandingan antara hasil observasi dengan hasil wawancara guru.

Berdasarkan fenomena dan hasil pengamatan melalui observasi serta wawancara pada siswa di kelas XI SMA Laboratorium Undiksha. Dari sebelas kelas yang peneliti amati, ternyata banyak siswa yang memiliki kebutuhan mandiri dan tanggung jawab yang sesuai dengan kepribadian dirinya untuk memperoleh pengakuan dari orang lain. Namun juga ada beberapa siswa yang menunjukkan kepribadian mandiri dan tanggung jawab yang tinggi (Self Exhibition). Berdasarkan gejala yang ditunjukan oleh siswa di atas, maka siswa tersebut dapat dikatakan menunjukkan gejala "self exhibition" yang rendah.

Untuk mengatasi masalah yang berkaitan dengan Self exhibition yang rendah dapat dilakukan berbagai pendekatan, antara lain : (1) pendidikan, (2)pelatihan, (3) bimbingan, (4) konseling. Dalam penelitian ini lebih menekankan pada tingkah laku (behavior), maka peneliti memilih pendekatan bimbingan konseling.

Berdasarkan pemaparan tentang Bimbingan dan Konseling di atas, adapun salah satu cara yang dapat digunakan untuk mengubah perilaku negatif menjadi perilaku yang lebih positif yaitu dengan Konseling Behavioral. Konseling kognitif behavioral adalah proses yang dilakukan untuk mengembangkan self 
exhibition dengan langkah-langkah sebagai berikut : 1) mengidentifikasi perilaku, 2) menganalisis perilaku, 3) menyimpulkan perilaku, 4) menyimpulkan indikator-indikator perilaku, 5) mendiagnosa perilaku, 6) melakukan prognosa perilaku, 7) mentreatmen perilaku, 8) mengevaluasi perilaku, 9) merefleksi perilaku, 10)memfollow-up perilaku.

Menurut Dharsana (2014:258) bahwa behavioral adalah suatu teori dan juga suatu usaha berdasarkan percobaan untuk menjelaskan prinsip dan kaidah-kaidah bagaimana tingkah laku manusia dipelajari. Sedangkan menurut Walker \& Shea (dalam Komalasari, 2011: 141) menjelaskan bahwa konseling behavioral mempunyai asumsi dasar bahwa setiap tingkah laku dapat dipelajari, tingkah laku lama dapat diganti dengan tingkah laku baru, dan manusia memiliki potensi untuk berperilaku baik dan buruk, tepat atau salah. Menurut Rosjidan (dalam Dharsana 2014:585) "tujuan umum terapi behavior adalah menciptakan kondisi-kondisi baru untuk belajar. Asumsinya bahwa pengalaman belajar yang demikian itu akan dapat memperbaiki tingkah laku bermasalah".

Dari beberapa uraian definisi tersebut di atas dapat disimpulkan bahwa konseling behavioral adalah proses pembentukan respon-respon tingkah laku dengan prosedur dan langkah yang telah ditentukan. Kelebihan dari teori behavioral ini adalah teori ini cocok diterapkan untuk melatih anak-anak yang masih membutuhkan dominasi bantuan orang dewasa dan teori ini membiasakan guru bersifat jeli dan peka terhadap situasi dan kondisi belajar. Sebaliknya ada kelemahan dari teori ini yaitu proses pembelajaran berpusat pada guru sehingga siswa hanya mendengarkan penjelasan dan menghapal saja sehingga menjadi tidak aktif dan berkembang.

Gejala "self exhibition" diatas, akan dapat berkembang manakala disentuh dan di"treatmen" dengan cara atau teknik yang selaras dengan teori konseling. Adapun beberapa teknik menurut corey ( dalam Dharsana $2014: 587$ ) dalam penerapan teori behavioral atau tingkah laku antara lain : 1) Desensitisasi Sistematik,2)Teknik-teknik pembanjiran, 3) Latihan Asertif, 4) terapi aversi, 5) pengondisian operan, 6) penguatan positif, 7) pembalikan, 8) pembentukan respon (shaping), 9) perkuatan intermiten, 10) penghapusan, 11) percontohan (modeling), 12) token economy. 13) relaksasi.

Teknik yang digunakan dalam penelitian ini yaitu teknik modeling. Menurut Bandura (dalam Dharsana 2014:591) "teknik modeling merupakan observasipermodelan, mengobservasi seseorang lainnya sehinggaseseorang tersebut membentuk ide dan tingkah laku, kemudiandijelaskan sebagai panduan untuk bertindak".Penelitian teknik modeling memiliki prosedur yaitu: 1) menyebarkan lembaran kuesioner self exhibition, 2) menganalisis hasil kuesioner self exhibition, 3) menulis dan menyajikan RPBK yang terkait dengan teknik relaksasi, 4) melakukan treatmen dengan menggunakan teknik modeling.

Layanan Konseling yang akan diberikan dalam penelitian ini adalah melalui empat tahapan, yaitu bimbingan klasikal, bimbingan kelompok, konseling kelompok kemudian konseling individual, dimana dalam keempat setting tersebut akan ditekankan pada teknik modeling.

Berdasarkan pemaparan, pemikiran serta fakta yang terjadi di lapangan, peneliti mengangkat tema tentang "self exhibition" yang akan dikembangkan menggunakan teknik modeling dalam model konseling Behavioral. Teknik ini akan diuji pengaruhnya dalam mengembangkan "self exhibition". Dalam hal ini, peneliti akan melakukan treatment terhadap beberapa siswa di kelas XI SMA

\section{Metode}

Penelitian ini dilakukan pada siswa kelas XI SMA Laboratorium Undiska Singaraja, Kabupaten Buleleng, Bali dengan pengambilan sampel menggunakan teknik Proposive Sampling. Variabel terikat dalam penelitian ini adalah Self Exhibition, sedangkan variabel bebasnya adalah konseling kognitif behavioral dengan strategi managemen diri dengan mempertimbangkan variabel moderator berupa urutan kelahiran siswa. Dalam kegiatan awal, peneliti melakukan observasi untuk melihat secara langsung tingkah laku siswa di kelas yang akan dijadikan sampel penelitian yang kemudian dideskripsikan sebagai gejalagejala prilaku dimana wawancarapun di lakukan sebagai informasi penguat kemungkinan-kemungkinan penyebab dari munculnya gejala tersebut.

Rancangan dalam penelitian ini menggunakan desain penelitian "Nonrandomized Control Group Pretes-Postest Group Desain" dimana dalam pelaksanaanya di awali dengan pemberian layanan bimbingan klasikal dan dilanjutkan pada pemberian layanan bimbingan kelompok hingga konseling 
kelompok. Kepada siswa yang dilihat belum mampu mengembangkan Self Exhibition dalam dirinya akan dilanjutkan pada treatmen berupa layanan konseling individual. Pada akhir treatmen akan diadakan kegiatan Post-Test kepada siswa sampel berupa pemberian kuesioner Self Exhibition, untuk melihat pengaruh konseling behavioral denganteknik modeling terhadap Self Exhibition siswa.

Jenis penelitian yang digunakan dalam penelitian ini adalah penelitian "eksperimen" dengan rancangan penelitian yaitu Control Group Pretes-Postest Group. Dalam penelitian ini peneliti mengadakan perlakuan (strategi), metode eksperimen mencoba meneliti perbandingan antara kedua kelompok yaitu kelompok eksperimen dan kelompok control. Dalam sebuah pelaksanaan eksperimen haruslah terdapat perlakuan (strategi), yaitu sesuatu yang mungkin menjadi sebuah penyebab. Sedangkan efek dari perlakuan itu disebut dengan hasil (output). Hal yang menjadi penyebab itu disebut variabel bebas (independent variable) sedangkan efeknya disebut variabel terikat (dependent variable). Untuk mengetahui adanya efek, diperlukan suatu perbandingan.

Teknik pengambilan sampel yang digunakan adalah teknik "Simple Random Sampling" dengan cara undian. Sehingga, dapat diketahui sampel dalam penelitian ini adalah siswa kelas XI IS dan XI IB.

Metode yang digunakan untuk mengumpulkan data adalah observasi, kuesioner,wawancara dan buku harian. Instrumen yang digunakan berupa lembaran pernyataan atau pertanyaan yang diberikan kepada responden secara langsung.

\section{Hasil dan Pembahasan}

Data hasil observasi yang dilaksanakan dalam setiap layanan model konseling behavioral teknik modeling, dapat diketahui bahwa terjadi penurunan gejala-gejala Self exhibition siswa kelompok eksperimen I yang bersifat (-) pada setiap layanan yang diberikan. Dalam bimbingan klasikal, terdapat 9 orang siswa yang menunjukkan gejala-gejala Self exhibition negatif (-) yang selanjutnya direkomendasikan mengikuti bimbingan kelompok. Kemudian dalam bimbingan kelompok, 5 orang siswa menunjukkan gejala-gejala Self exhibition negatif (-) yang selanjutnya direkomendasikan mengikuti konseling kelompok. Selanjutnya dalam konseling kelompok, 3 orang siswa menunjukkan gejala-gejala Self exhibition negatif (-) yang selanjutnya mengikuti konseling individu. Setelah pelaksanaan layanan model konseling behavioral teknik modeling, seluruh siswa kelompok eksperimen I sudah mampu menunjukkan gejala-gejala Self exhibition yang positif (+). Sehingga, pemberian treatment pada kelompok eksperimen I dengan model konseling behavioral teknik modeling memberikan pengaruh yang positif terhadap Self exhibition siswa.

Hasil wawancara terhadap siswa kelompok eksperimen dapat diketahui bahwa terdapat sebagian siswa yang mengalami gejala-gejala Self exhibition rendah sepertibeberapa siswa jarang mengerjakan pekerjaan sampai selesai, tidak mau berusaha menyelesaikan pekerjaan sampai tuntas, tidak mau bekerja keras pada suatu tugas. Secara kualitatif, hasil wawancara yang dilakukan terhadap kelompok eksperimen dalam setiap layanan model konseling behavioral teknik modeling dan teknik relaksasi mengalami penurunan Self exhibition yang bersifat negatif (-). Hal ini menunjukkan bahwa terdapat perubahan gejala-gejala Self exhibition siswa menjadi lebih positif (+). Sehingga, dalam kelompok eksperimen ini pemberian model konseling behavioral teknik modeling dan teknik modeling berkontribusi positif terhadap Self exhibition siswa.

Hasil data buku harian dimbil pada salah satu orang siswa bernama kadek ayu kartini. Berdasarkan data hasil buku harian yang dibuat oleh kadek ayu kartini maka dapat diketahui bahwa terjadi peningkatan skor buku harian a.n.kadek ayu kartini dalam setiap layanan yang diberikan. Sehingga, dari buku harian dan mingguan ini dapat diketahui bahwa pelaksanaan treatment yang dilakukan berkontribusi positif terhadap Self exhibition yang dimiliki oleh kadek ayu kartini.

Berdasarkan hasil pelaksanaan Post-Test pada kelompok eksperimen menggunakan kuesioner self exhibition, dapat diketahui bahwa 18 orang siswa berada dalam kategori sangat tinggi, 5 orang siswa berada dalam kategori tinggi, dan 1 orang siswa berada dalam kategori sedang sedangkan hasil pelaksanaan Pre-Test pada kelompok kontrol menggunakan kuesioner self exhibition, dapat diketahui bahwa 3 orang siswa berada dalam kategori sangat tinggi, 23 orang siswa berada dalam kategori tinggi, 3 orang siswa berada pada kategori sedang. 
Pembahasan hasil penelitian yang dipaparkan pada bagian ini adalah hasil-hasil analisis deskriptif dan analisis statistik yang meliputi: Teknik Modeling dalam Model Konseling Behavioral Efektif terhadap Self exhibition melaluilesson study Siswa XI IS

Siswa kelas XI IS SMA Laboratorium Undiksha, berdasarkan hasil pengamatan telah menunjukkan gejala-gejala seperti tidak mengerjakan pekerjaan sampai selesai, tidak mau berusaha mengerjakan pekerjaan sampai tuntas, dan tidak bekerja keras pada suatu tugas. Gejala-gejala tersebut diatas, merupakan gejala Self exhibition yang rendah. Sehingga, gejala-gejala tersebut penting untuk diperhatikan agar siswa memiliki pribadi exhibition yang stabil.

Untuk melakukan treatment terhadap Self exhibition siswa yang rendah tersebut, dalam layanan bimbingan konseling terdapat berbagai macam teori konseling yang dapat diaplikasikan salah satunya yaitu teori konseling behavioral. Model konseling behavioral adalah proses pembentukan respon-respon tingkah laku dengan prosedur dan langkah yang telah ditentukan model konseling behavioral ini bersifat konfrontatif dan aktif, membawa aspek-aspek masa lalu yang relevan ke saat sekarang, pengaplikasian model konseling behavioral ini memerlukan teknik. Dalam hal ini, untuk memberikan treatment terhadap Self exhibition siswa, teknik yang digunakan adalah teknik modeling. Teknik modeling adalah adalah cara untuk memberikan peniruan-peniruan terhadap kepribadian yang ada sehingga disaksikan dan diterapkan oleh individu. Dalam hal ini, teknik modeling diaplikasikan dalam model konseling behavioral berupa layanan bimbingan klasikal, bimbingan kelompok, konseling kelompok, dan konseling individu pada siswa kelas XI IS SMA Laboratorium Undiksha sebagai kelompok eksperimen .

Hasil observasi yang dilakukan dalam setiap pelaksanaan layanan, menunjukkan bahwa terjadi penurunan jumlah siswa yang mengalami Self exhibition yang rendah. Hasil observasi dalam bimbingan klasikal menemukan 6 orang siswa yang menunjukkan gejala Self exhibition negatif yang selanjutnya direkomendasikan mengikuti bimbingan kelompok. Kemudian hasil observasi dalam bimbingan kelompok menemukan 4 orang siswa menunjukkan gejala Self exhibition negatif yang selanjutnya direkomendasikan mengikuti konseling kelompok. Selanjutnya hasil observasi dalam konseling kelompok menemukan 2 orang siswa menunjukkan gejala Self exhibition negatif yang selanjutnya direkomendasikan mengikuti konseling individu. Setelah dilakukan konseling individual, siswa sudah mampu menunjukkan gejalagejala Self exhibition yang bersifat positif. Dari data hasil observasi tersebut, dapat diketahui bahwa setelah diberikan treatment model konseling behavioral teknik modeling terjadi penurunan Self exhibition siswa yang bersifat negatif. Sehingga, jumlah siswa yang mengalami gejala-gejala Self exhibition yang rendah dapat berkurang.

Temuan empiris pada penelitian ini menyatakan bahwa teknik modeling dalam model konseling behavioral efektif terhadap Self exhibition siswa kelas XI IS. Hasil uji F diketahui bahwa kedua varians tidak homeogen dimana $\mathrm{F}$ hitung $>\mathrm{F}$ tabel $(2,42>1,84)$. Kemudian dilakukan uji t didapatkan hasil bahwa Harga $t$ hitung diperoleh 19,95dan Harga t tabel sebesar 1,69.. Jika dibandingkan Harga t hitung dengan Harga t tabel didapatkan bahwa 19,95 >1,69 artinya Harga t hitung $>$ Harga t tabel dengan db 33 dan 32 dan taraf siginifikansi $5 \%(\alpha=0,05)$. Ini berarti bahwa Ho ditolak dan Ha diterima. Untuk itu, hipotesis ke pertama yaitu teknik modeling model konseling behavioral efektif terhadap Self exhibition siswa kelas XI IS SMA Laboratorium Undiksha diterima. Sehingga dapat diketahui bahwa teknik modeling dalam model konseling behavioral efektif terhadap Self exhibition siswa kelas XI IS SMA Laboratorium Undiksha.

\section{Kesimpulan}

Berdasarkan hasil penelitian dapat disimpulkan bahwa, (1) Siswa kelas XI IS SMA Laboratorium Undiksha, menunjukkan gejala-gejala self exhibition yang rendah. Gejala-gejala tersebut penting untuk diperhatikan agar pribadi exhibition siswa stabil. Untuk itu, treatment Model Konseling Behavioral teknik modeling, merupakan alternatif solusi terhadap permasalahan tersebut. (2) Model Konseling Behavioral teknik modeling telah terbukti efektif dalam mengembangkan self exhibition siswa. Temuan empiris menyatakan bahwa terdapat perbedaan antara teknik modeling model konseling behavioral pada saat digunakan untuk men treatment self exhibition siswa. 


\section{Referensi}

Dharsana, Ketut. (2013). Modul Teori-Teori Konseling. Singaraja: Jurusan Bimbingan Konseling, FIP UNDIKSHA

. (2014). Model-Model Teori, Teknik, Skill Bimbingan Konseling untuk Penulisan RPBK, Proposal, Sripsi, Tesis. Singaraja: BK FIP UNDIKSHA

Sukardi. (2012). Metodelogi Penelitian Pendidikan Kompetensi dan Praktiknya. Jakarta: PT Bumi Aksara

Aguiton, C., Cardon, D., Castelain, A., Fremaux, P., Granjon, F., Nepote, C., ... Ziemlicki, C. (2009). Does showing off help to make friends? Experimenting a sociological game on self-exhibition and social networks. Artificial Intelligence, 38-40. Retrieved from charles.nepote@fing.org\%0A

Cogo, A., \& Dewey, M. (2006). Efficiency in ELF Communication: From Pragmatic Motives to LexicoGrammatical Innovation. Nordic Journal of English Studies, 5(2), 59-93. Retrieved from http://ub016045.ub.gu.se/ojs/index.php/njes/article/viewFile/65/69

Cova, B., \& Pace, S. (2006). Brand community of convenience products: new forms of customer empowerment - the case "my Nutella The Community." European Journal of Marketing, 40(9/10), 1087-1105. https://doi.org/10.1108/03090560610681023

Friedman, H. S., \& Miller-Herringer, T. (1991). Nonverbal display of emotion in public and in private: selfmonitoring, personality, and expressive cues. Journal of Personality and Social Psychology, 61(5), 766775. https://doi.org/10.1037/0022-3514.61.5.766

Lotte, F., \& Renard, Y. (2008). Self-Paced Brain-Computer Interaction with Virtual Worlds : A Quantitative and Qualitative Study " Out of the Lab." Applied Sciences, 3-8. Retrieved from https://hal.archives-ouvertes.fr/file/index/docid/304340/filename/bci-wtc08.pdf

ML Hamilton. (2002). The Fourth International Conference on Self-Study of Teacher Education Practices Making a Difference in Teacher Education Through Self-Study Volume 1 Table of Contents Volume 1,1,1-114. Retrieved from https://s3.amazonaws.com/academia.edu.documents/46380785/Exploring_the_Concept_of_Dialog ue_in_the20160610-508-

eok9hj.pdf?AWSAccessKeyId=AKIAIWOWYYGZ2Y53UL3A\&Expires $=1512377627 \&$ Signature $=9$ 1PSccND9cwUWbCd\%2Fa4X\%2BiWNAB4\%3D\&response-content-disposition=inline\%3B filename\%3DExploring_the_Concept_of_Dialogue_in_the.pdf

Nielsen, M., \& Dissanayake, C. (2004). Pretend play, mirror self-recognition and imitation: A longitudinal investigation through the second year. Infant Behavior and Development, 27(3), 342-365. https://doi.org/10.1016/j.infbeh.2003.12.006

Salmi, H., Vainikainen, M. P., \& Thuneberg, H. (2015). Mathematical thinking skills, self-concept and learning outcomes of 12-year-olds visiting a mathematics science centre exhibition in Latvia and Sweden. Journal of Science Communication, 14(4), 1-19. Retrieved from https://jcom.sissa.it/sites/default/files/documents/JCOM_1404_2015_A03.pdf

Zhao, X., Salehi, N., \& Naranjit, S. (2013). The many faces of Facebook: Experiencing social media as performance, exhibition, and personal archive. Proceedings of the ..., 1-10.

https://doi.org/10.1145/2470654.2470656 
The authors declare that they have no significant competing financial, professional or personal interests that might have influenced the performance or presentation of the work described in this manuscript.

Copyrights Holder: Gusti Agung Aditya Nata Putra, Ketut Dharsana, Ari Darmayanti 2017

First Publication Right: BISMA The Journal of Counseling

https://doi.org/10.23887/128172017

Open Access Article | CC-BY Creative Commons Attribution 4.0 International License.

Word Count: 